\title{
Geo-Information based Soil Fertility Status of Deogarh District of Odisha, India
}

\author{
Srikanta Kumar Sethy", Antaryami Mishra², Prava Kiran Dash ${ }^{2 *}$, \\ Subhashis Saren ${ }^{2}$ and Pradip Dey ${ }^{3}$ \\ ${ }^{1}$ Department of Horticulture, Nabarangpur, Odisha-764059, India \\ ${ }^{2}$ Department of Soil Science and Agricultural Chemistry, Odisha University of Agriculture \\ and Technology, Bhubaneswar, Odisha-751003, India \\ ${ }^{3}$ Indian Institute of Soil Science, Bhopal-462001, India
}

Keywords

Soil Fertility, GPS, GIS

Article Info

Accepted:

04 November 2019

Available Online:

10 December 2019

\section{A B S T R A C T}

The present investigation has been designed to analyse the Geo-information based soil fertility status and to prepare GPS-GIS based soil fertility maps with respect to soil $\mathrm{pH}$, organic carbon, available $\mathrm{N}, \mathrm{P}$ and $\mathrm{K}$ for soils of Deogarh district located in North-Western Plateau Agroclimatic Zone of Odisha, India. Results revealed that, soil $\mathrm{pH}$ varied from 3.8 to 8.3 with a mean value of 5.5; that of soil organic carbon from 0.2 to $18.0 \mathrm{~g} \mathrm{~kg}^{-1}$ with a mean value of $6.6 \mathrm{~g} \mathrm{~kg}^{-1}$. Soils are safe for all types of crop production with respect to the soluble salt content. Soil available $\mathrm{N}$ content varied from 87.5 to $237.5 \mathrm{~kg} \mathrm{ha}^{-1}$ with a mean value of $123.5 \mathrm{~kg} \mathrm{ha}^{-1}$; that of available $\mathrm{P}$ content from 4.0 to $65.3 \mathrm{~kg} \mathrm{ha}^{-1}$ with a mean value of $13.8 \mathrm{~kg} \mathrm{ha}^{-1}$ and that of available $\mathrm{K}$ from 37.0 to $787.0 \mathrm{~kg} \mathrm{ha}^{-1}$ with a mean value of $288.4 \mathrm{~kg} \mathrm{ha}^{-1}$.

\section{Introduction}

Soil test based fertility management is an effective tool for of agricultural soils that have high degree of spatial variability which find out the soil fertility related production constraints of the study area and suggest the remedial measures for optimum production of the crops (Rawal et al., 2018). Global Positioning Systems and Geographic Information Systems (GPS-GIS) can be efficiently use for monitoring soil fertility status (Thombare et al., 2017). Fertilizer use can be better optimised by utilizing knowledge of 'soil fertility maps' prepared with the help of Geographical Information System (GIS) (Dash et al., 2018). GPS based soil fertility evaluation also helps in monitoring the soil health from time to time (Swain et al., 2019). Taking these concepts into cognizance, an attempt has been made to analyse soil fertility status with respect to basic soil physico- 
chemical properties and primary macronutrients of an agriculturally important district of Odisha namely Deogarh (earlier Debagarh). Total 358 numbers of GPS based soil samples were analysed and GPS-GIS based soil fertility maps were prepared for key soil properties, which can be highly beneficial in guiding the farmers, manufactures and planners.

\section{Materials and Methods}

Deogarh district has a geographical area of $2781.66 \mathrm{~km}^{2}$ with gross cropped area and cropping intensity of 1,08,000 ha and $189 \%$ respectively. The District is in between longitude $84^{\circ} 28^{\prime}-85^{\circ} 15^{\prime}$ East and latitude $21^{\circ} 11^{\prime}-21^{\circ} 43^{\prime}$ North with a mean altitude of 630 feet above Mean Sea Level (MSL) in the North-Western Plateau Zone Agroclimatic Zone of Odisha. The district shares borders with Sambalpur, Sundargarh and Angul districts. It constitutes 3 development blocks namely Barkote, Reamal and Tileibani. All the three Blocks of the district namely Tileibani, Reamal and Barkote mostly drain to the river Brahmani, which is the most important river flowing through this district (Mishra, 1988). The lands of the district have very high degree of slope. The elevation gradually decreases on the south eastern part on either side of the river Brahmani. The agricultural land of the district can be marked to have five landforms such as hill, ridges, valley, levee and stream terrace which can be further divided into different land types and sub land types with distinct physiographic units (Mishra, 1985). The climate of this region is hot, moist, sub humid with dry summer \& mild winter. Mean annual rainfall is $1582 \mathrm{~mm}$. The mean maximum and mean minimum temperature is $38^{\circ} \mathrm{C}$ and $18^{\circ} \mathrm{C}$ respectively.

Total 358 numbers of GPS based composite soil samples from different blocks of Deogarh District namely Barkote (102), Reamal (137) and Tileibani (119) were collected using GPS instrument (Garmin make; model: 76MAPCSx). Soils were analysed for $\mathrm{pH}(1: 2)$ (Jackson, 1973), EC(1:2) (Jackson, 1973), organic carbon (Walkley and Black, 1934), available nitrogen (Subbiah and Asija, 1956), phosphorus (Bray and Kurtz, 1945) and potassium (Hanway and Heidel, 1952). Base map of the study area was geo-referenced and digitized. Latitude, Longitude and soil analysis data were entered into attributed table and linked to Arc GIS software for making thematic soil fertility maps.

\section{Results and Discussion}

\section{Soil reaction}

Soil $\mathrm{pH}$ of Deogarh district was found to be varying from 3.8 to 8.3 with a mean value of 5.5. In Barkote block, soil reaction or $\mathrm{pH}$ varied from 3.9 to 6.6 ; that of Reamal block from 4.0 to 8.3 and that of Tileibani block from 3.8 to 6.7. The mean value of soil $\mathrm{pH}$ in Barkote, Reamal and Tileibani blocks were observed to be 5.4, 5.9 and 5.4 respectively (Table 1). GPS and GIS based map for soil $\mathrm{pH}$ of Deogarh district has been presented in Figure 1. Soils of Deogarh district were detected to be extremely acidic (10.3\%), very strongly acidic (15.4\%), strongly acidic (26.3\%), moderately acidic (27.7\%), slightly acidic $(11.7 \%)$ and neutral to alkaline $(8.7 \%)$. Most of soils of the study area (92.7\%) were identified to be suffering from different levels of soil acidity. Hence, soil acidity is the most challenging soil related crop production constraint of the area.

\section{Electrical conductivity}

Soil EC of Deogarh district was found to be varying from 0.001 to $0.93 \mathrm{dSm}^{-1}$ with a mean value of $0.1 \mathrm{dSm}^{-1}$. In Barkote block, EC varied from 0.001 to $0.68 \mathrm{dSm}^{-1}$; that of Reamal block from 0.001 to $0.51 \mathrm{dSm}^{-1}$ and 
that of Tileibani block from 0.005 to 0.93 $\mathrm{dSm}^{-1}$. The mean value of soil $\mathrm{pH}$ in Barkote, Reamal and Tileibani blocks were observed to be $0.2, \quad 0.1$ and $0.2 \mathrm{dSm}^{-1}$ respectively. Electrical Conductivity (1:2) of surface soil samples of the entire study area was found to be less than $2 \mathrm{dSm}^{-1}$ (Table 1). Hence, soils of the study area are safe for all types of crop production with respect to the soluble salt content.

\section{Organic carbon}

Soil OC of Deogarh district was found to be varying from 0.2 to $18.0 \mathrm{~g} \mathrm{~kg}^{-1}$ with a mean value of $6.6 \mathrm{~g} \mathrm{~kg}^{-1}$. In Barkote block, OC content varied from 0.7 to $16.8 \mathrm{~g} \mathrm{~kg}^{-1}$; that of Reamal block from 0.2 to $17.0 \mathrm{~g} \mathrm{~kg}^{-1}$ and that of Tileibani block from 0.3 to $18.0 \mathrm{~g} \mathrm{~kg}^{-1}$. The mean value of OC in Barkote, Reamal and Tileibani blocks were observed to be 7.0, 6.2 and $6.9 \mathrm{~g} \mathrm{~kg}^{-1}$ respectively (Table 1). GPS and GIS based map for soil OC of Deogarh district has been presented in Figure 2. Soil organic carbon status of major parts of Deogarh district were detected to be medium $(50.0 \%)$ and low (34.9\%); whereas only $15.1 \%$ of soils were observed to be high in organic carbon status. High organic carbon status not only promote microbial activity of the soil, but also helps in providing different nutrient elements in their plant available forms in to the soil solution (Singh et al., 2018). Hence, enriching the soils with organic carbon by addition of organic matter to the soil will help in optimising crop productivity and sustaining soil health.

\section{Available nitrogen}

Soil available N content of Deogarh district was found to be varying from 87.5 to $237.5 \mathrm{~kg}$ $\mathrm{ha}^{-1}$ with a mean value of $123.5 \mathrm{~kg} \mathrm{ha}^{-1}$. In Barkote block, available $\mathrm{N}$ content varied from 87.5 to $162.5 \mathrm{~kg} \mathrm{ha}^{-1}$; that of Reamal block from 87.5 to $175.0 \mathrm{~kg} \mathrm{ha}^{-1}$ and that of Tileibani block from 87.5 to $237.5 \mathrm{~kg} \mathrm{ha}^{-1}$. The mean value of available $\mathrm{N}$ content in Barkote, Reamal and Tileibani blocks were observed to be $121.6,125.1$ and $123.3 \mathrm{~kg} \mathrm{ha}^{-1}$ respectively (Table 2). GPS and GIS based soil fertility map for available $\mathrm{N}$ of Deogarh district has been presented in Figure 3. The soils of entire district was found to be low $(100 \%)$ with respect to available $\mathrm{N}$ content. Low $\mathrm{N}$ content can be attributed to prevailing soil acidity condition (Palwe and Yelwe, 2018).

\section{Available phosphorus}

Soil available $\mathrm{P}$ content of Deogarh district was found to be varying from 4.0 to $65.3 \mathrm{~kg}$ $\mathrm{ha}^{-1}$ with a mean value of $13.8 \mathrm{~kg} \mathrm{ha}^{-1}$. In Barkote block, available $\mathrm{P}$ content varied from 4.0 to $65.3 \mathrm{~kg} \mathrm{ha}^{-1}$; that of Reamal block from 5.0 to $64.3 \mathrm{~kg} \mathrm{ha}^{-1}$ and that of Tileibani block from 6.6 to $54.3 \mathrm{~kg} \mathrm{ha}^{-1}$. The mean value of available $\mathrm{P}$ content in Barkote, Reamal and Tileibani blocks were observed to be 13.8 , 13.7 and $14.2 \mathrm{~kg} \mathrm{ha}^{-1}$ respectively (Table 2).

GPS and GIS based soil fertility map for available $\mathrm{P}$ of Deogarh district has been presented in Figure 4. The available $\mathrm{P}$ status of major portion of soils of Deogarh district was found to be low $(54.7 \%)$ and medium $(43.3 \%)$; whereas only $2 \%$ of soils were identified to be high with respect to available $\mathrm{P}$ status. Available $\mathrm{P}$ content is greatly dependent on organic carbon status and microbial activity of the soils. The low to medium status of available $\mathrm{P}$ can be well correlated to existing organic carbon status. Such type of available phosphorus status was also noticed in the soils of Odisha during fertility mapping (Mishra et al., 2014; Mishra et al., 2017). 
Table.1 Soil chemical properties of Deogarh District

\begin{tabular}{|c|c|c|c|c|c|c|c|}
\hline Sl. No & \multirow{2}{*}{ Block } & \multicolumn{2}{|c|}{$\mathbf{p H}(\mathbf{1 : 2})$} & \multicolumn{2}{c|}{$\mathbf{E C}\left(\mathbf{d S m}^{-\mathbf{1}}\right)$} & \multicolumn{2}{c|}{$\mathbf{O C}\left(\mathbf{g ~ k g}^{-1}\right)$} \\
\cline { 3 - 8 } & Name & Range & Mean & Range & Mean & Range & Mean \\
\hline $\mathbf{1}$ & Barkote & $3.9-6.6$ & 5.4 & $0.001-0.68$ & 0.1 & $0.7-16.8$ & 7.0 \\
\hline $\mathbf{2}$ & Reamal & $4.0-8.3$ & 5.9 & $0.001-0.51$ & 0.1 & $0.2-17.0$ & 6.2 \\
\hline $\mathbf{3}$ & Tileibani & $3.8-6.7$ & 5.4 & $0.005-0.93$ & 0.1 & $0.3-18.0$ & 6.9 \\
\hline
\end{tabular}

Table.2 Soil available nutrient status of Deogarh District

\begin{tabular}{|c|c|c|c|c|c|c|c|}
\hline \multirow[t]{2}{*}{ Sl. No } & \multirow[t]{2}{*}{$\begin{array}{l}\text { Block } \\
\text { Name }\end{array}$} & \multicolumn{2}{|c|}{$\underset{1}{A})$} & \multicolumn{2}{|c|}{$\underset{1}{\text { Available }} \mathbf{P}$ (kg ha } & \multicolumn{2}{|c|}{$\begin{array}{c}\text { Available K (kg } \\
\left.\text { ha }^{-1}\right)\end{array}$} \\
\hline & & Range & Mean & Range & Mean & Range & Mean \\
\hline 1 & Barkote & $87.5-162.5$ & 121.6 & $4.0-65.3$ & 13.8 & $\begin{array}{l}37.0- \\
787.0\end{array}$ & 297.6 \\
\hline 2 & Reamal & $87.5-175.0$ & 125.1 & $5.0-64.3$ & 13.7 & $\begin{array}{l}62.0- \\
610.0\end{array}$ & 282.0 \\
\hline 3 & Tileibani & $87.5-237.5$ & 123.3 & $6.6-54.3$ & 14.2 & $\begin{array}{l}57.0- \\
631.0\end{array}$ & 287.9 \\
\hline
\end{tabular}

Fig.1 Soil pH map of Deogarh District

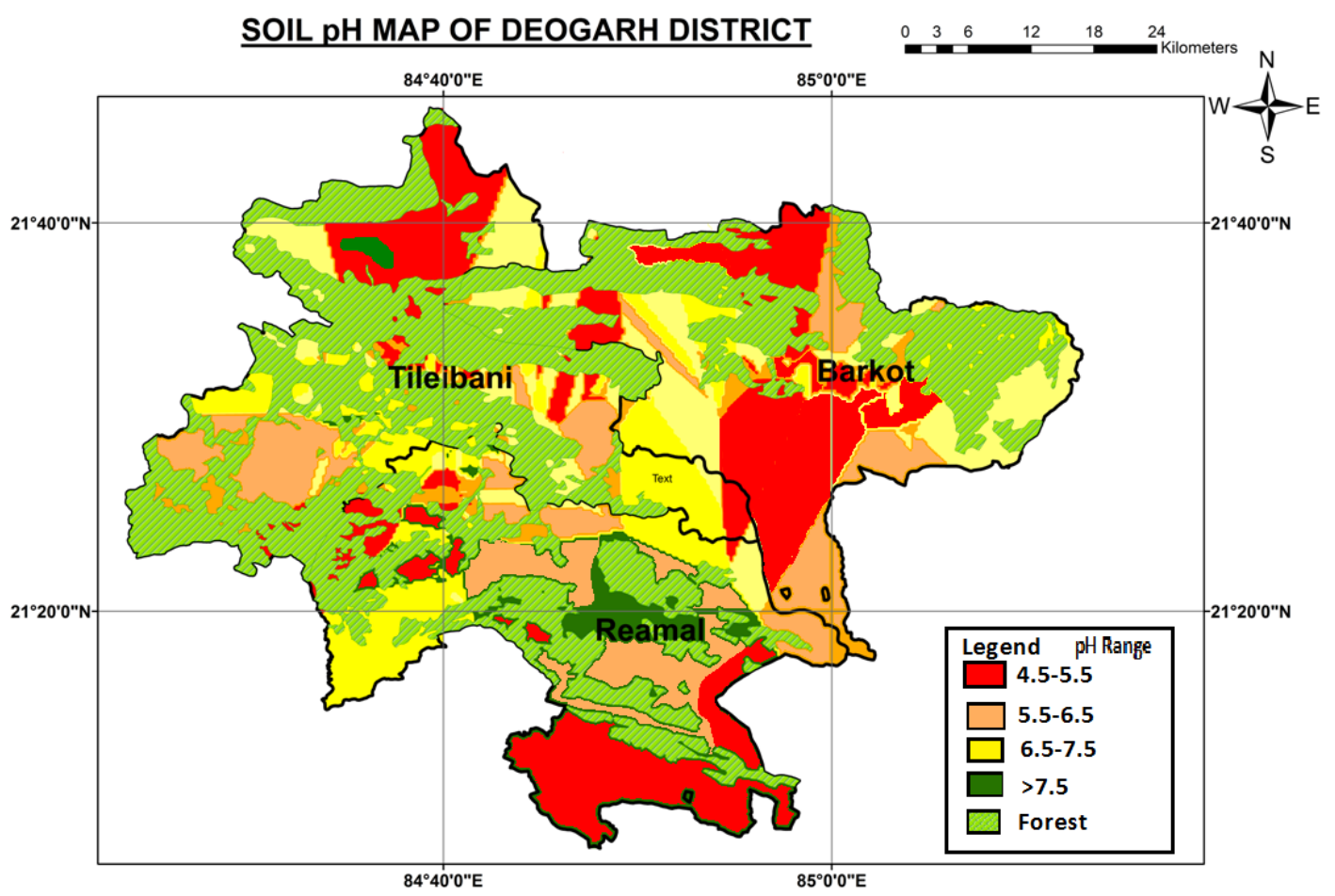


Fig.2 Soil organic carbon map of Deogarh District

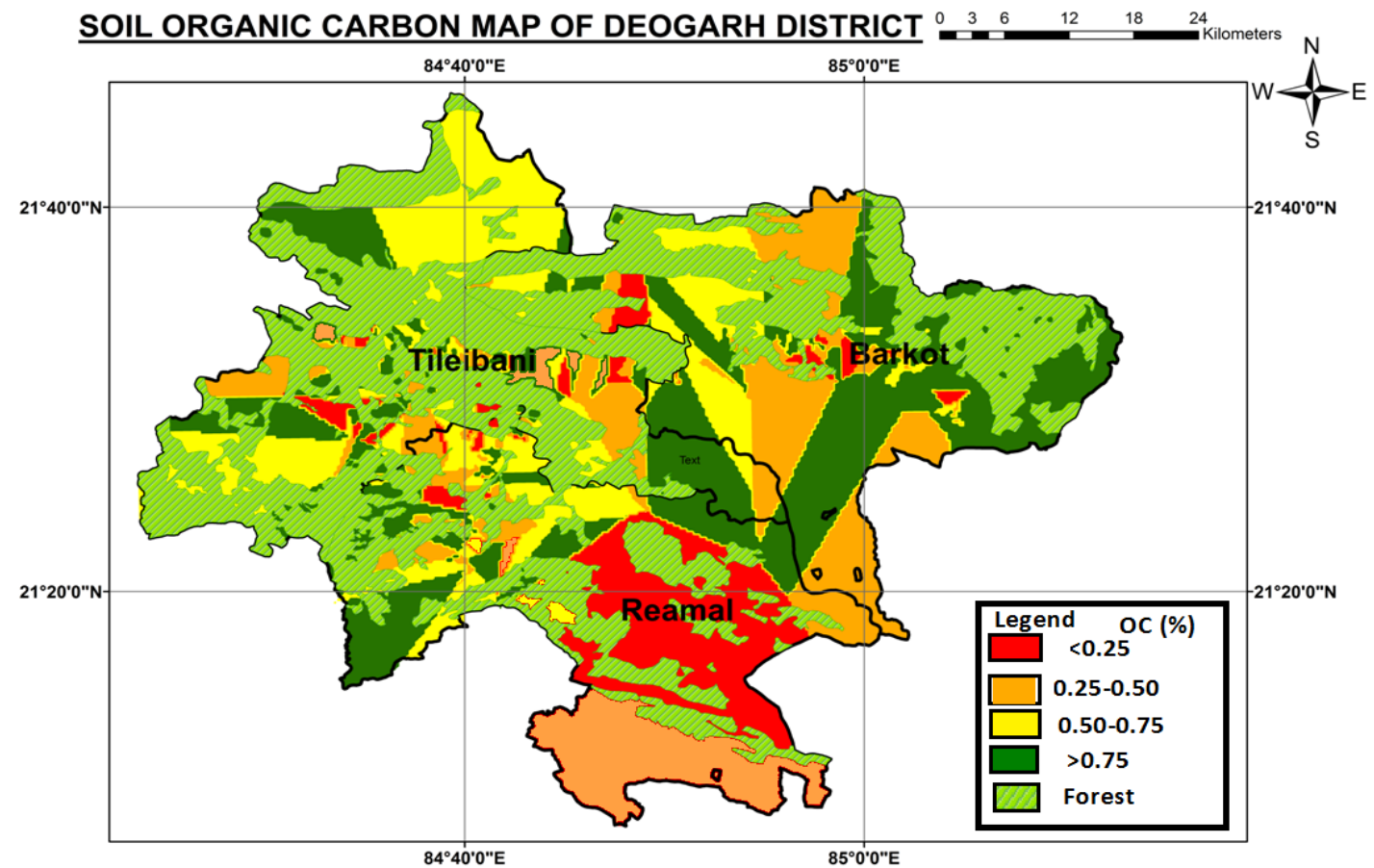

Fig.3 Available nitrogen map of Deogarh District

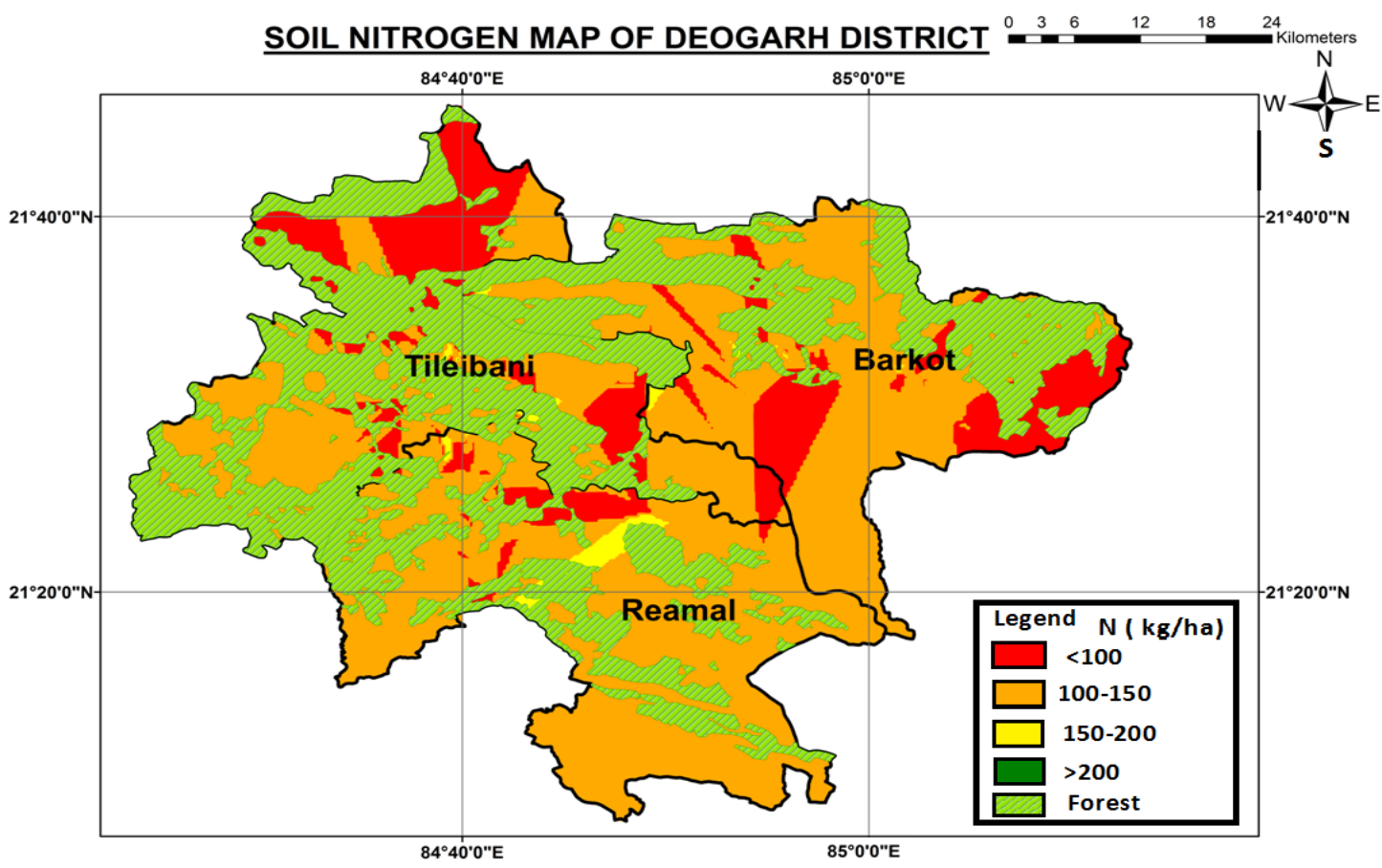


Fig.4 Available phosphorus map of Deogarh District

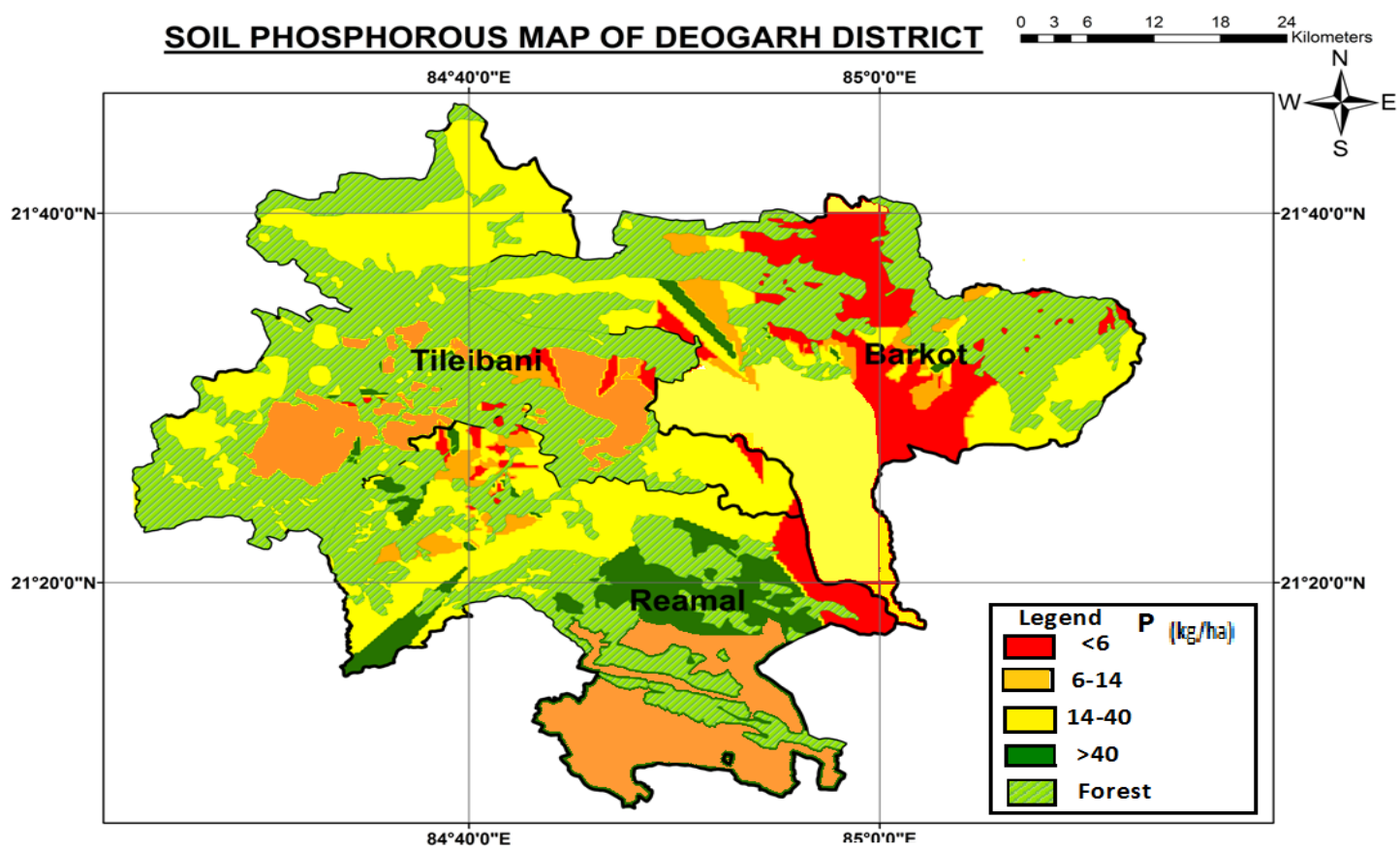

Fig.5 Available potassium map of Deogarh District

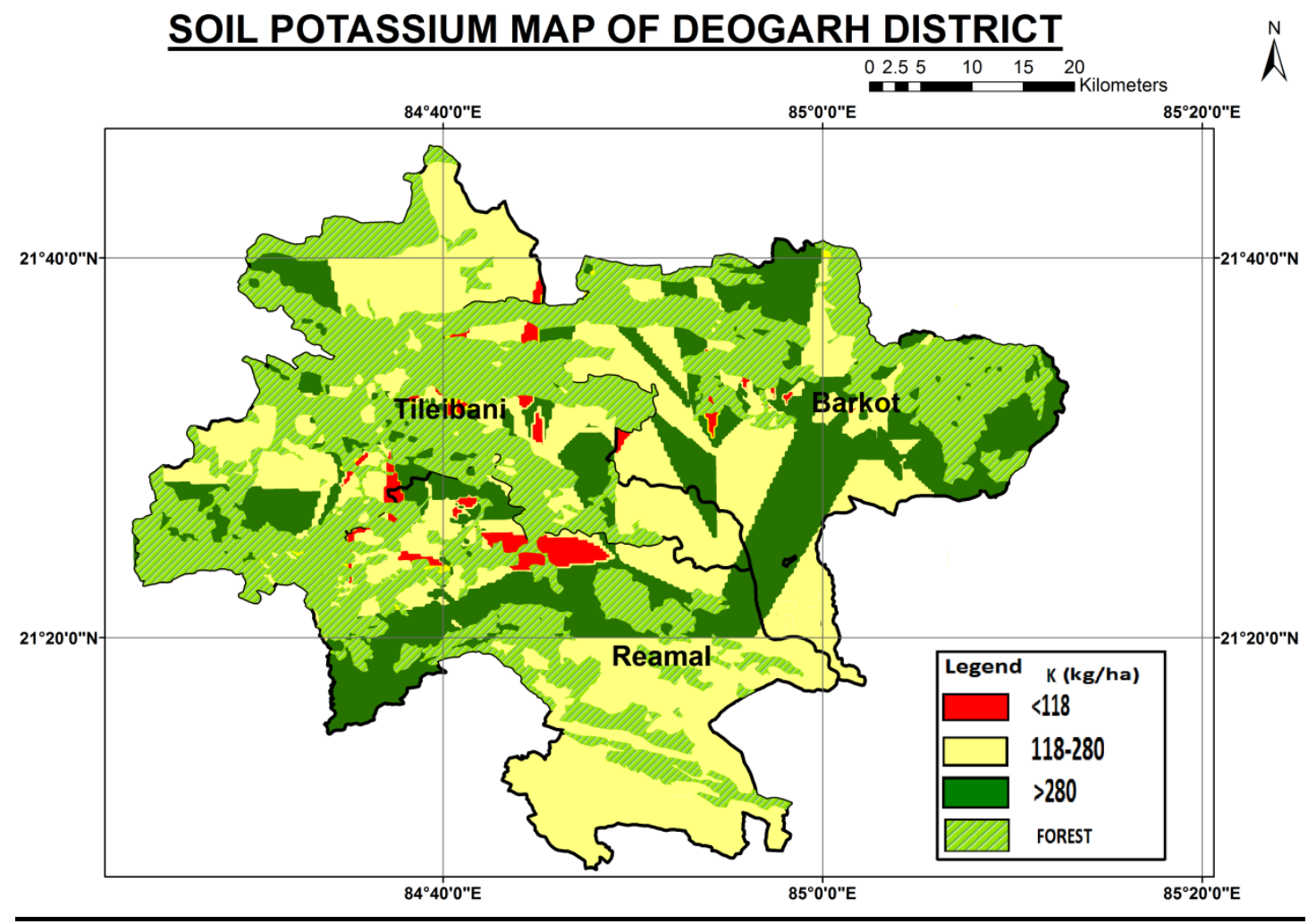




\section{Available potassium}

Soil available K content of Deogarh district was found to be varying from 37.0 to $787.0 \mathrm{~kg}$ $\mathrm{ha}^{-1}$ with a mean value of $288.4 \mathrm{~kg} \mathrm{ha}^{-1}$. In Barkote block, available $\mathrm{K}$ content varied from 37.0 to $787.0 \mathrm{~kg} \mathrm{ha}^{-1}$; that of Reamal block from 62.0 to $610.0 \mathrm{~kg} \mathrm{ha}^{-1}$ and that of Tileibani block from 57.0 to $631.0 \mathrm{~kg} \mathrm{ha}^{-1}$. The mean value of available $\mathrm{K}$ content in Barkote, Reamal and Tileibani blocks were observed to be $297.6,282.0$ and $287.9 \mathrm{~kg} \mathrm{ha}^{-1}$ respectively (Table 2). GPS and GIS based soil fertility map for available K of Deogarh district has been presented in Figure 5. The available K status of soils of Deogarh district was found to be medium (53.9\%), high $(41.9 \%)$ and low $(4.2 \%)$. The medium and high $\mathrm{K}$ status can be attributed to $\mathrm{K}$ bearing parent materials of the district. Variation in available potassium across the soils was noticed by several workers (Chitdeshwariet al., 2017; Mishra et al., 2016; Mishra et al., 2015).

Present study revealed that $92.7 \%$ of soils of Deogarh district are being affected by different levels of soil acidity. Soil acidity has not only many adverse effects on soil physical, chemical, biological properties but also it greatly hamper the availability of many nutrient elements to the plants. Hence, soil acidity is the most important soil related crop production constraint for the soils of Deogarh district. Suitable low cost liming materials must be applied to soils based on lime requirement. Addition of sufficient organic matter to the soils not only help in enhancing the organic carbon status of the soils but also enhance the microbial activity leading to increased release of plant nutrients into the soil solution. Hence, enriching the soils with organic carbon by addition of organic matter to the soil is highly recommended The EC of the soils was in safe range for all types of crop production. The soils of entire district were found to be low with respect to available $\mathrm{N}$ content, which is one of the most important challenges for higher crop production. Hence, application of nitrogenous fertilizers along with organic manures and soil ameliorant (lime) is of great importance to deal with soil acidity and low $\mathrm{N}$ availability. The available $\mathrm{P}$ status was mostly low to medium in range, which constituted $98 \%$ of the soil samples studied. Hence, application of soil test based phosphatic fertilizers along with organic manures and soil ameliorant (lime) is of great importance to increase $\mathrm{P}$ availability to crops. The available $\mathrm{K}$ status was mostly medium to high in range, which constituted $95.8 \%$ of the soil samples studied. Hence, application of only recommended doses of fertilizers in most parts of the district (having medium range of available $\mathrm{K}$ ) will be sufficient to support optimum crop production. Even recommended doses of fertilizers can be reduced to $25 \%$, where available K status is high. Since, most of the $\mathrm{K}$ fertilizers are imported and costly, a reduced application of $\mathrm{K}$ fertilizers will reduce the cost of cultivation. An integrated application of soil test based fertilizer doses, along with sufficient organic matter and suitable ameliorants can optimise crop productivity along with sustaining soil health.

\section{References}

Bray, RH. and Kurtz, Lt.1945. Determination of total, organic and available forms of phosphorus in soils. Soil Science. 59: 39-45.

Chitdeshwari, T., Santhi, R., Radhika, K., Sivagnanam, S., Hemalatha, S., Dey, P. and Rao, S. 2017. GPS and GIS Based Soil Fertility Mapping for Cuddalore District of Tamil Nadu. Madras Agric. J. 104 (7-9): 251-257.

Dash, P. K., Mishra, A., Saren, S., Revathi, B., and Sethy, S. K. 2018. Preparation of GPS and GIS Based Soil Fertility Maps and Identification of Soil 
Related Crop Production Constraints of RRTTS and KVK Farm, Dhenkanal Located in the Mid-Central Table Land Agro Climatic Zone of Odisha, India. International Journal of Chemical Studies. 6 (5): 934-943.

Hanway, J. J., and Heidel, H. 1952. Soil analysis methods as used in Iowa State College Soil Testing Laboratory. Iowa State College Bulletin. 57: 1-31.

Jackson, ML.1973. Soil Chemical Analysis. Prentice Hall of India. Private limited, New Delhi.

Mishra, A., Das, D., Saren, S. and Dey, P. 2015. GPS and GIS Based Soil Fertility Maps of Puri District of Coastal Odisha. Journal of Indian Society of Coastal Agricultural Research. 33 (2): 7-11.

Mishra, A., Das, D., Saren, S. and Dey, P. 2016. GPS and GIS based soil fertility maps of Nayagarh District, Odisha. Annals of Plant and Soil Research. 18 (1): 23-28.

Mishra, A., Das, D., Saren, S. and Dey, P. 2017. GPS and GIS based soil fertility maps of Bhadrak District of Odisha, India. Eco. Env. \& Cons. 23 (1): 184190.

Mishra, A., Pattnaik, T., Das, D. and Das, M. 2014. Soil Fertility Maps Preparation Using GPS and GIS in Dhenkanal District, Odisha, India. International Journal of Plant \& Soil Science. 3(8): 986-994.

Mishra, D.P. 1985. Soil and Land Irrigability Classification. Directorate of Soil Conservation, Govt. of Odisha.

Mishra, D.P. 1988. Crop Zones of Sambalpur
District, Orissa. Directorate of Agriculture, Govt. of Odisha.

Palwe, C. R. and Yelwe, L. J. 2018. GPS-GIS Based Soil Fertility Status of Mahatma Phule Krishi Vidyapeeth, Rahuri, (M.S.), India. International Journal of Agriculture Innovations and Research. 7 (2): 2319-1473.

Rawal, N., Acharya, K. K., Bam, C. R., Acharya, K. 2018.Soil Fertility Mapping of Different VDCs of Sunsari District, Nepal Using GIS. Int. J. Appl. Sci. Biotechnol. 6(2): 142-151.

Singh, G., Kumar, B. and Shashikant. 2018. Soil Fertility Mapping Using Remote Sensing and GIS in NSP Farms of ND University of Agriculture and Technology, Kumarganj, Faizabad, Uttar Pradesh, India. International Journal of Current Microbiology and Applied Science.7: 1394-1402.

Subbiah, B. V., and Asija, G. L. 1956. A rapid procedure for the determination of available nitrogen in soils. Current Science. 25259-25260.

Swain, N., Mishra, A., Saren, S., Dash, P. K., Digal, M. and Mishra, B. B. 2019. Soil Fertility Status of Some Villages in Khordha and Bhubaneswar Block of Khordha District under North Eastern Ghat Agro Climatic Zone of Odisha, India. International Journal of Current Microbiology and Applied Sciences. 1(8): 2319-7706.

Walkley, A. J., and Black, I. A. 1934. Estimation of soil organic carbon by the chromic acid titration method. Soil Science; 37: 29-38.

\section{How to cite this article:}

Srikanta Kumar Sethy, Antaryami Mishra, Prava Kiran Dash, Subhashis Saren and Pradip Dey. 2019. Geo-Information based Soil Fertility Status of Deogarh District of Odisha, India. Int.J.Curr.Microbiol.App.Sci. 8(12): 255-262. doi: https://doi.org/10.20546/ijcmas.2019.812.036 